\title{
Preventive Peer-educational Activities: What can Medical Students do to Potentially Save Lives?
}

\author{
Phillipe Abreu-Reis, Flávio Tomasich, Bruno Eduardo Scheffer Pinto, Marília França Madeira Manfrinato, Luísa Bor-
} dignon Oliveira, Adonis Nasr, Helena Slongo, Juliana Boni Cruz, Iwan Collaço

\begin{abstract}
Background: Traffic injuries are among the main causes of death worldwide. Even with the advances in technology, there are still $50 \%$ of deaths that cannot be reduced by medical care improvement. These important injuries can though be reduced by prevention of trauma. One of the best ways to address this issue is through incorporating preventive measures to the daily routine of schools. It is the aim of this study to assess children's perception on traumatic events and to introduce a cost-effective peer-education preventive action.
\end{abstract}

Study design: A prospective interventional comparative study with children from a basic school in South Brazil. Aquestionnaire with 9 decision-making questions about traffic scenarios was applied by volunteer medical students from May to June 2012, before and after a peer-educational lecture on prevention of traffic injuries. There were 20 epidemiological questions as well. Data collected was compared between the pre and the posttests of the same students. Statistical analysis was performed using the Chi-square for discrete, and the students' t-test for continuous variables.

Results: Among 246 students answered the questionnaires. The mean age was 10.19 years old. $21 \%$ reported that always crosses the street alone, while $47 \%$ only cross with an adult. Most of the students said they always cross-streets in the zebra-crossing and look to both sides before crossing $(60.71$ and $84.9 \%$ respectively). Impressively, $12.55 \%$ said they often/ sometimes drive a car or a motorcycle. Also, $30.76 \%$ ride a bike in between the cars. Furthermore, $77.48 \%$ of the students use the front seat of the car. Regarding safety issues, only one-third have a horn in their bikes, and less than half use helmet when playing. When comparing their assessments, there was a higher number of correct answers in the decision-making section in the post-test (5.21 vs 3.93, $\mathrm{p}=0.000001161)$. The estimated overall cost was 45 dollars.

Conclusion: Preventive measures urge to be incorporated to schools curricula. Peer-educational actions are a cost-effective for spreading medical knowledge among children and youth.

Keywords: Trauma education, Peer activities, Prevention, Children, Traffic.

How to cite this article: Abreu-Reis P, Tomasich F, Pinto BES, Manfrinato MFM, Oliveira LB, Nasr A, Slongo H, Cruz JB, Collaço I. Preventive Peer-educational Activities: What can Medical Students do to Potentially Save Lives? Panam J Trauma Critical Care Emerg Surg 2012;1(3):182-185.

Source of support: Nil

Conflict of interest: None declared

\section{RESUMEN}

Introducción: Lesiones decurrentes de accidentes de tránsito están entre las causas principales de muerte en el mundo. Aunque en la actualidad tengamos muchos avanzos tecnológicos, $50 \%$ de las muertes no pueden ser reducidas por la mejoría de la atención médica. Sin embargo este contingente de víctimas podría ser reducido por la prevención del trauma. Una de las mejores maneras de actuar en este problema es incorporando enseñamientos de manera cotidiana en las escuelas. El objetivo del estudio es analizar la percepción de los niños sobre los accidentes de tránsito y a partir de allí introducir acciones educativas, preventivas y sustentables.

Métodos: Estudio prospectivo comparativo de intervención con niños de una escuela básica en el sur de Brasil. Fue aplicado un cuestionario de 9 preguntas, donde el niño debía tomar decisiones sobre escenarios de tránsito. Las preguntas son hechas a los niños por estudiantes de medicina voluntarios, en el periodo de mayo a junio de 2012. El mismo cuestionario fue aplicado antes y después de una conferencia educativa sobre la prevención de los accidentes de tránsito. Hubo también 20 preguntas epidemiológicas. Los datos colectados fueron comparados entre el pre y el post-testes de los mismos estudiantes. El análisis estadístico se realizó utilizando el Chicuadrado para aplicaciones discretas, y el "ensayo t de Student para las variables continuas.

Resultados: Respondieron a los cuestionarios 246 niños. La media de edad fue de 10,19 años. Dijeron que siempre cruzan la calle solos $21 \%$ de los entrevistados, mientras que el $47 \%$ sólo cruzan con la compañía de un adulto. La mayoría de los estudiantes dijeron que siempre cruzan la calle en el paso de peatones y miran a ambos lados antes de cruzar $(60,71 \%$ y $84,9 \%$ respectivamente). Respuesta sorprendente fue que $12,55 \%$ afirmaron que a menudo conducen un coche o una motocicleta. Andan de bicicleta entre los coches el $30,76 \%$ de los entrevistados. Como pasajeros en los coches, $77,48 \%$ de los niños utilizan el asiento delantero. En cuestiones de seguridad sólo una tercera parte tienen bocina (Timbre u otro señal sonoro) en su bicicleta, y menos de la mitad usan casco de protección cuando jugando. Al comparar sus evaluaciones, había un mayor número de respuestas correctas en la sección de la toma de decisiones en el post-test $(5,21$ vs 3,93, p = $0,000001161)$. El estimado costo total de la acción educativa fue de 45 dólares.

Conclusión: Las medidas de prevención necesitan ser incorporados a los currículos de las escuelas. Acciones preventivas por educación entre pares son una solución sustentable para la difusión de los conocimientos médicos entre los niños y los jóvenes.

Palabras claves: Educación trauma, Prevención, Niños en el tránsito.

\section{INTRODUCTION}

Traffic injuries are amongst the main causes of death worldwide. Considering Brazilian data, there were 929,240 admissions to hospitals due to external causes and 141,227 deaths related to trauma. ${ }^{1}$ For the 5-year period 2005 to 2009 , external causes are the third leading cause of death in Brazil

Paper presented at the student competition, 25th Annual Congress of Panamerican Trauma Society, Medellin, Colombia, November 2012. 
(12.57\%), exceeded only by heart disease and cancer. ${ }^{2}$ This prevalence is also observed in the international literature, but mainly because of the aging process of population and the increasing incidence of cancer, those disease tend to overcome the external causes.

Nevertheless, considering all sorts of external causes (falls, drownings, assaults, etc.), traffic injuries constitute a significant portion, accounting for more than $25 \%$ of deaths. About deaths occurring on public roads, 32.9\% were due to traffic injuries, only exceeded by assaults $(39.7 \%) .^{2}$ These data make clear the importance of preventing deaths related to external causes, especially regarding traffic accidents, which should be seen as a real problem of public health. In Brazil, South region accounts for the third place in hospital admissions ranking. In 2010, the state of Parana alone had more than 70,000 admissions, being $24.28 \%$ only in the city of Curitiba (capital city). The total number of deaths in the state was 9,491 people $(1,440$ at Curitiba). ${ }^{2}$

However, even with the advances in technology, there are still $50 \%$ of deaths that cannot be reduced by medical care improvement (the first mode of the trimodal distribution of deaths in trauma). ${ }^{3}$ These important injuries can though be reduced by prevention of trauma. One of the best ways to address this issue is through incorporating preventive measures to the daily routine of elementary schools. Children have a greater capability of absorbing knowledge and will potentially spread information throughout their lives.

On the other hand, Academic Leagues are interest groups composed of medical students from different semesters of medical school, developing activities under the supervision of professors and doctors of the academic hospital. These associations play an important role in medical education, enhancing knowledge and promoting activities in specific areas that are weak in the general medical curriculum of the universities. ${ }^{4-6}$ Being composed of medical students allows these associations to be dynamic and make it possible to acquire knowledge and experience by exposing these students early to practice.

Furthermore, a Trauma Academic League aims to spread the concepts of 'trauma disease' which is fundamental to improve the quality of care and its efficiency. Nevertheless, it is necessary to fight against trauma with preventive measures from all levels of the society, from single person actions to governmental policies to enhance both pre-hospital and in-hospital trauma care.

It is known that by the practice of peer-education it is easier to establish an effective communication way, reflecting in better understanding of the one who receive the information given by peers. ${ }^{7-13}$

It is the aim of this study to assess children's perception on traumatic events surveyed by medical students as well as to introduce a cost-effective peer-education preventive action to be adopted worldwide.

\section{METHODS OF RESEARCH}

A prospective interventional comparative cohort study with children from a basic school in South Brazil. The chosen school was Padre Durval Cech, in the city of Colombo-PR (metropolitan region of Curitiba-PR). A survey with a large number of questions on road safety issues, traffic behavioral issue and 9 decision-making questions about traffic scenarios was applied by volunteer medical students of the Hospital do Trabalhador/Federal University of Parana, from May to June 2012, before and after a peer-educational lecture on prevention of traffic injuries. There were 20 epidemiological questions as well.

The peer-educational lecture was developed by the group of researchers, ranging from basic traffic behavioral skills to complex traffic injuries related to car crashes and their epidemiological data.

Data collected was compared between the pre- and the post-tests of the same students. Statistical analysis was performed using the Chi-square for discrete, and the Students' t-test for continuous variables.

\section{RESULTS}

Among 246 students were surveyed, being 133 girls and 113 boys. The mean age was 10.19 years old.

As it is shown in Figure 1, 21.82\% reported that always cross-streets alone, while $45.07 \%$ only cross with an adult and $11.56 \%$ always cross the street with another child.

Most of the students said they always cross-streets in the zebra-crossing and look to both sides before crossing (60.71 and 84.9\% respectively) (Fig. 2). Almost two-thirds of children drop-off the car in the sidewalk, while $57.46 \%$ never drop-off in the middle of the street. Impressively, $12.55 \%$ said they often/sometimes drive a car or a motorcycle. About

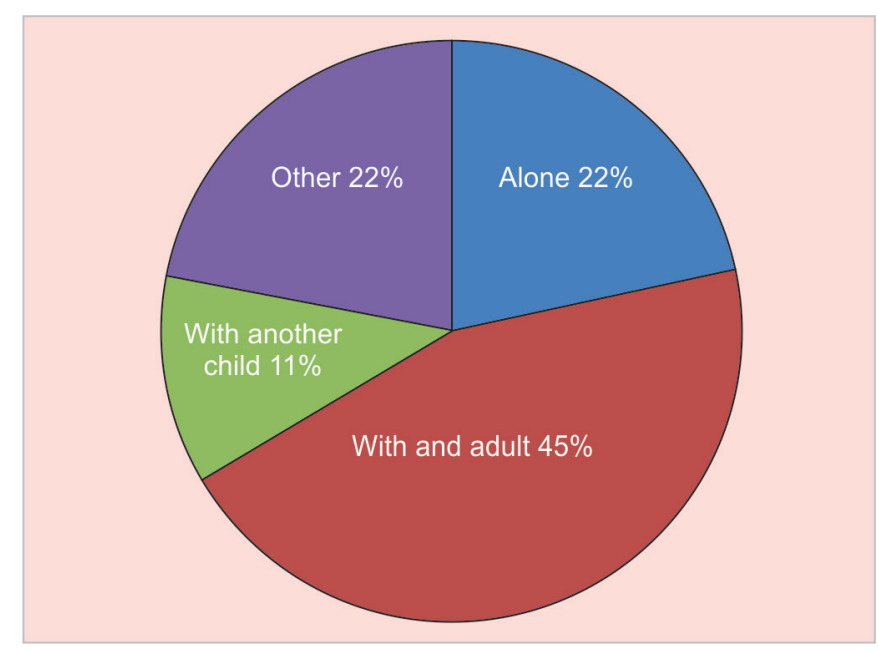

Fig. 1: Street crossing issues 


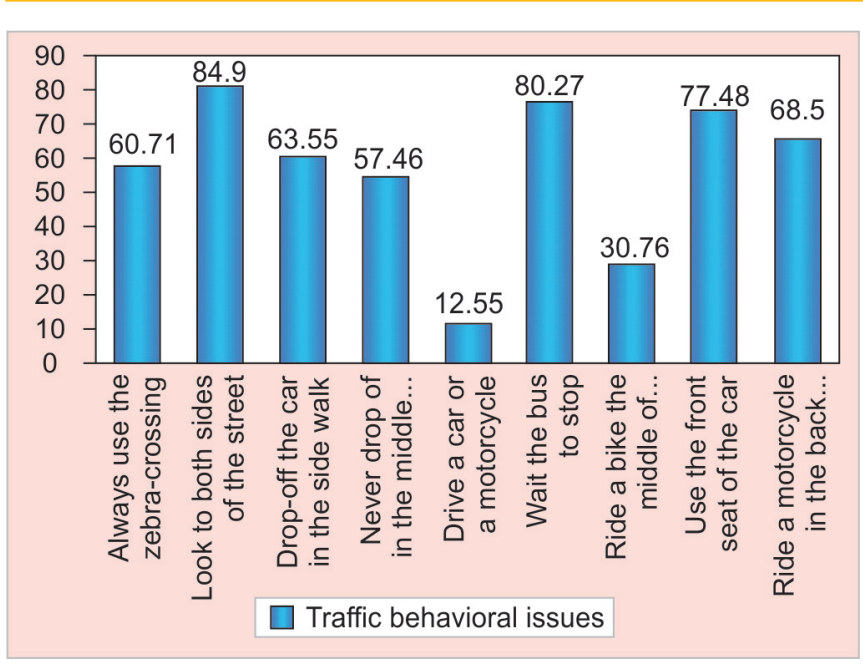

Fig. 2: Traffic behavioral issues

4 over every 5 children said that wait for the bus to stop before standing up to drop-off. Also, $30.76 \%$ ride a bike in between the cars. Furthermore, $77.48 \%$ of the students use the front seat of the car.

When asked about playing in the street, most of them said the always play with another child, however almost $10 \%$ said they even play alone, with no adult supervision (Fig. 3).

Regarding safety issues (Fig. 4), only one-third have a horn in their bikes, and less than half use helmet when playing. Moreover, $40.8 \%$ use elbow and knee protection and $88.08 \%$ use their own seat-belt in the car. Nevertheless, about one-third use colorful bright clothes to ride a bike, although $43.04 \%$ said they have night signs in the bike and its pedals. Only $29.58 \%$ of them reported using a baby special seat in the car, and one fifth have a mirror in their bikes. On the other hand, $68.9 \%$ reported using elevated road-crosses.

When comparing their survey assessments, there was a higher number of correct answers in the decision-making section in the post-test $(5.21 \mathrm{vs} 3.93, \mathrm{p}=0.000001161)$ (Table 1).

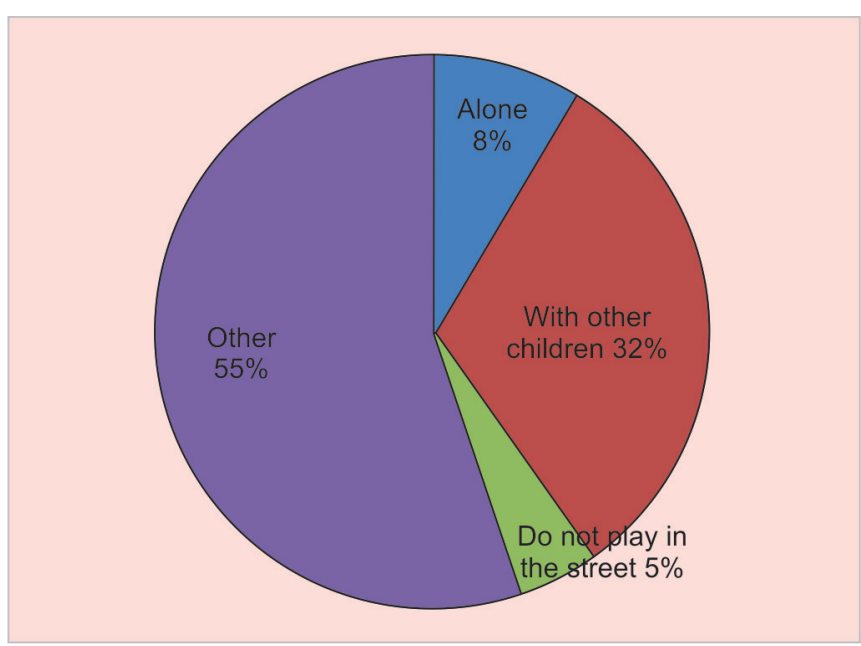

Fig. 3: With whom play in the street

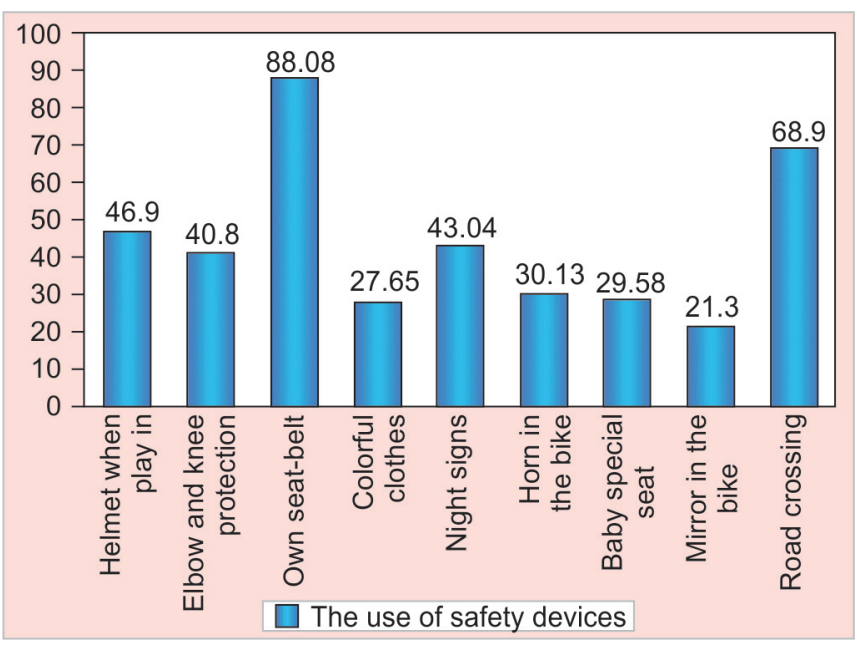

Fig. 4: The use of safety devices

The estimated overall cost was 45 dollars, with photocopies and transportation of the team (Table 2).

\begin{tabular}{|c|c|c|}
\hline Pre-test & Post-test & $p$-value \\
\hline $3.93 \pm 2.66$ & $5.21 \pm 3.09$ & 0.000001161 \\
\hline \multicolumn{3}{|c|}{ Table 2: Cost of the activity } \\
\hline \multirow{2}{*}{\multicolumn{2}{|c|}{500 photocopies (0.05 USD each) }} & 25 \\
\hline & & 20 \\
\hline \multicolumn{2}{|c|}{$\begin{array}{l}\text { Iransportation of } \zeta \text { medical students } \\
\text { Total }\end{array}$} & 45 USD \\
\hline
\end{tabular}

\section{DISCUSSION}

Our data show important facts of the Brazilian culture, even in a Southern city with a expected better social development: Low use of safety devices in traffic situations associated with a poor preventive traffic behavior.

Considering that the study was performed with young children (10-y-o), it is quite impressive that $12 \%$ of them drive a car or motorcycle as well as that $68.5 \%$ ride a motorcycle in the back position. It is especially remarkable when we take into account that a motorcycle accident always eject the victim from the vehicle, what represents a 6 times increase in the odds to have a severe injury.

Nevertheless, one-fifth said they cross the street alone. It is expected that a 10-year-old child has difficulties in crossing a street, mainly in a busy city like the one where the study was performed. As a matter of fact, only $60 \%$ of them always cross the street in the zebra-crossing, and about 15\% denies to look to both sides before crossing it, what reflect the weak preparedness of them in this issue.

Furthermore, one-third reported to ride a bike in between the cars, confirming the lack of warn from traffic accidents. Also, only a quarter of them denies to use the front seat of the car, even being prohibited by the Brazilian law to do it before they are 11 . 
This data are even worse when looking for traffic safety issues, as only one-third have a horn in their bikes, and less than half use helmet when playing. Impressively, less the a half of them use bright clothes and night shining signs when riding their bikes.

In spite of the statistically significance of the rise in the number of correct answers in the decision-making section in the post-test, children still had a low number of success (5.21 over 9). The previous knowledge they had was probably the greatest limitation in this assessment, since they correctly answered the survey in only about one-third of the pre-test. However, the peer-educational activity was proven to be a success, as well as cheap enough to be implemented in the medical curricula all over the world.

About 45 dollars to peer educate traffic preventive measures to 246 children under 12 years old, representing an estimated cost of 18 cents for each is quite a good deal, and should be encouraged in different parts of the globe.

\section{CONCLUSION}

Preventive measures urge to be incorporated to schools curricula and peer-educational actions are a cost-effective for spreading medical knowledge amongst children and youth.

\section{REFERENCES}

1. Ministério da Saúde - Governo Federal. Sistema de Informações em Saúde. Datasus. Morbidade e Mortalidade no Brasil por Causas Externas. Available in $<$ http://www.datasus.gov.br $>$. Acesso em 25 jul 2011.

2. Ministério da Saúde - Governo Federal. Sistema de Informações em Saúde. Datasus. Mortalidade Brasil - Óbitos segundo causa. Available in <http://tabnet.datasus.gov.br/cgi/tabcgi.exe?sim/ cnv/obt10uf.def $>$, Access in July/2012.

3. American college of surgeons-committee on trauma advanced trauma life support (ATLS). Course Manual: Course Generalities. Chicago, (8th ed) 2010(1):1-10.

4. de Pinho TA, et al. O 'Currículo Paralelo' dos estudantes de Medicina da Universidade Federal de Minas Gerais. Revista Brasileira de Educação Médica 2007;31(3):254-65.

5. Martins PC, Santos AA, Britto GS. Atividades extracurriculares: multiplicidade e diferenciação necessárias ao currículo. Revista Brasileira de Educação Médica. Rio de Janeiro, 2007 [citado em 10 ago 2011] 31(3); 203-11.

6. Pêgo-Fernandes PM, Wassum MA. O ensino médico além da graduação: ligas acadêmicas. Diagnósticos e Tratamento. 2011; 16(2):50-51.

7. Houston M, Cassabaum V, Matzick S, Rapstine T, Terry S, Uribe $\mathrm{P}$, et al. Mile-High Regional Emergency Medical and Trauma Advisory Council (MHRETAC). Teen traffic safety campaign: Competition is the key. J Trauma 2010 Mar;68(3):511-14.

8. Knobe M, Münker R, Sellei RM, Holschen M, Mooij SC, Schmidt-Rohlfing B, Niethard FU, Pape HC. Peer teaching: a randomised controlled trial using student-teachers to teach musculoskeletal ultrasound. Med Educ 2010 Feb;44(2): 148-55.
9. Wang X, Zhu Y. Peer education's effects on preventing accidental injuries in middle school students. Wei Sheng Yan Jiu 2009 Jul;38(4):449-51.

10. Philbrook JK, Franke-Wilson NA. The effectiveness of a peer lead smart driving campaign on high school students' driving habits. J Trauma 2009 Jul;67(1 Suppl):S67-69.

11. Goslar PW, Silvers M, Strever T, Judkins D, Segebarth P, Lerma C. Lessons from a statewide pilot of the battle of the belts project in a state without a primary seat belt law. J Trauma. 2009 Jul;67(1 Suppl):S62-66.

12. Germeni E, Lionis C, Davou B, Petridou ET. Understanding reasons for non-compliance in motorcycle helmet use among adolescents in Greece. Inj Prev 2009 Feb;15(1):19-23.

13. Waitzkin H, Yager J, Parker T, Duran B. Mentoring partnerships for minority faculty and graduate students in mental health services research. Acad Psychiatry 2006 May-Jun;30(3):205-17.

\section{ABOUT THE AUTHORS}

\section{Phillipe Abreu-Reis (Corresponding Author)}

Medical Student, Hospital do Trabalhador, State Health Secretary of Paraná, Federal University of Paraná, Curitiba-PR, Brazil, e-mail: phillipeareis@gmail.com

\section{Flávio Tomasich}

Professor, Hospital do Trabalhador, State Health Secretary of Paraná Federal University of Paraná, Curitiba-PR, Brazil

\section{Bruno Eduardo Scheffer Pinto}

Medical Student, Hospital do Trabalhador, State Health Secretary of Paraná, Federal University of Paraná, Curitiba-PR, Brazil

\section{Marília França Madeira Manfrinato}

Medical Student, Hospital do Trabalhador, State Health Secretary of Paraná, Federal University of Paraná, Curitiba-PR, Brazil

\section{Luísa Bordignon Oliveira}

Medical Student, Hospital do Trabalhador, State Health Secretary of Paraná, Federal University of Paraná, Curitiba-PR, Brazil

\section{Adonis Nasr}

Professor, Hospital do Trabalhador, State Health Secretary of Paraná Federal University of Paraná, Curitiba-PR, Brazil

\section{Helena Slongo}

Medical Student, Hospital do Trabalhador, State Health Secretary of Paraná, Federal University of Paraná, Curitiba-PR, Brazil

\section{Juliana Boni Cruz}

Medical Student, Hospital do Trabalhador, State Health Secretary of Paraná, Federal University of Paraná, Curitiba-PR, Brazil

\section{Iwan Collaço}

Academic Director, Hospital do Trabalhador, State Health Secretary of Paraná, Federal University of Paraná, Curitiba-PR, Brazil 